\title{
INVESTIGATING THE RELATIONSHIPS BETWEEN LIFE SATISFACTION AND LEISURE SATISFACTION ON INDIVIDUALS INTERESTED IN OUTDOOR RECREATION: SAMPLE OF PARKS IN LONDON
}

\author{
Tolga BEŞİKÇI*, Tennur YERLISU LAPA**, Pınar GÜZEL* \\ *ManisaCelal Bayar University, Faculty of Sports Science, Turkey \\ **Akdeniz University, Faculty of Sports Science, Turkey
}

\begin{abstract}
The main purpose of this study is to determine the relationship between life satisfaction and leisure satisfaction of individuals participating leisureactivities within outdoor recreation. A total of 500 individuals, (females $n=298$ and males $n=202$ ) aged 12 to 65 participated in this study, who were interested in outdoor recreation in parks in London, England. The research sample was randomly selected. These participants were individuals that participated outdoor recreation and leisure activities as a volunteer. Within the scope of the survey study, two different scales were used. At the same time, demographic variables of participants were questioned. The questionnaire form consisted of the following two scales; "The Satisfaction with Life Scale (SWLS)" developed by Diener et al. (1985) adapted to Turkish by Köker and Yetim (1991), and "Leisure Satisfaction Scale (LSS)" developed by Beard \&Ragheb (1980) adapted to Turkish by Gökçe (2008).For an initial statistical representation of the data, descriptive and frequency analyses were performed. Pearson correlation coefficients were utilized to determine and interpret the existence and degree of correlations between scale mean scores. According to the findings of the study, a significantly moderate level of correlation was observed between participants' level of life satisfaction and leisure satisfaction $(r:, 36 ; p<.05)$. The results of the study show that individuals participating in outdoor recreation (parks) have a high level of life satisfaction and quality of life which in return provides positive psychological and physiological gains. In addition, individuals participating in outdoor recreation with a high level of leisure satisfaction are also expected to have a high level of life satisfaction. Thus, local authorities are suggested to pay special attention and focus on recreational activities and management of recreational areas such as parks.
\end{abstract}

Key Words: leisure, outdoor recreation, life satisfaction, leisure satisfaction

\section{Introduction}

Within the evolving and changing structure of society, highly working and productive individuals do not fully enjoy prosperity and peace.Working hard with strict programs leads to many individual and social problems such as alienation, non-conformity, spiritual dissatisfaction. The solutions of these problems reveal themselves with the understanding of increasing leisure time left behind from work, including recreation activities, which are far from turning back to work routine just after having rest (Kocyigit, Y1ld1z, 2014). These activities carried out in free time periods are the ones that individuals choose for their own satisfaction. These busy individuals have the opportunity to do something different than their daily routine, to acquire new skills, to reveal different aspects and socialize with new people.Places and areas where recreational activities are carried out for different purposes provide the ground for these opportunities.

From the past to the present, natural and open spaces, parks and gardens have become a kind of shelter where individuals can get away from the monotony of their daily routines and move away from the intensity of city life where they are more intothe nature.These areas showed functional differences according to societies' lifestyle and cultural structure for centuries(Ocak, 2006).Benefits to be achieved through activities especially in outdoor activities offer opportunities to participants to reduce the negativity brought by urban life.Individuals who want to take advantage of these opportunities are interested in recreation such as park and garden activities in their free time. In this way, outdoor can be seen as a heaven where many different recreational activities can be done.These areas allow for recreation in outdoor areas, from cycling to walking, group activities to individual games and many more free time activities (Calik, Beser, Ekinci, Kara, 2013).

\section{Outdoor Recreation}

It is a kind of recreation where individuals participate voluntarily in their free time with their own desires, where nature itself is used as a resource, activities are organized away from the concept of competition and sensitivity to the interpersonal relationship and 
environment is at the forefront. Outdoor Recreation consists of free time activities taking place in the natural environment of individuals about their natural environment and their interactions with this environment. Individuals who participate in these activities gain some experience in the natural field. By improving family and friend relationships especially in social dimension,this makes it easier for them to fulfil their daily life routines and help them find a more valuable place in society (Ardahan and Kaplan, 2017). In addition to this, the sedentary lifestylecaused by the developing technology and the stressful city life, the increase in population,urban problems and the environmental problems that arise with industrialization affect individuals negatively in terms of physiological, psychological and social aspects.It is thought that individuals move towards recreational activities outside the city and in outdoor areas in order to be away from these negativities and to be in a clean and active environment (Besikci, 2016).In these outdoor activities, individuals learn to act as a community, take responsibility and risks, discover their own abilities, and they provide individual satisfaction. This satisfaction with leisure can be associated with the social benefit of outdoor activities (Tutuncu, 2014).

\section{Leisure Satisfaction}

Individuals' satisfaction with leisure activitieswhich they choose on their own enables them to feel joy and happiness. This sense of satisfaction obtained in leisure is closely related to the quality that individuals perceive from their leisure assessment; in general, it expresses how satisfied individuals are in their free time (Kovacs, 2007: 42). In another definition, leisure satisfaction is expressed as "positive emotions that individuals acquire, gain, perceive with their participation to the leisure time activities" (Beardand Ragheb). With participation in leisure time activities, determining the benefits that individuals desire, their expectation from the activity or how happy they are with this activity, can provide important information in the subsequent activities to provide more enjoyable and satisfactory measures, to improve activities and to ensure diversity.

The activities that the individuals actively or passively participate in have positive effects on social life, including their interests in the life styles, integration into society, quality of life, and their individual satisfaction at the end of the activity (Ardahan and Yerlisu Lapa, 2011). The high level of leisure satisfaction increases the leisure participation and positively affects the life satisfaction of the individuals (Losier et. al., 1993). In this way, a direct relationship can be established between the individual's leisure evaluation and the satisfaction they provide.

\section{Life Satisfaction}

Life satisfaction is a concept in many studies on individuals who participate in recreational activities and which has a close relationship with leisure elements. This concept refers not only to the level of satisfaction of individuals in their own life, but also it can be defined as the emotional reaction of the individual against the life which is leisure, work and other non-work time (HongandGiannakopoulos, 1994).
Life satisfaction is an important factor in terms of the behaviour and health of individuals. A person with high life satisfaction is unlikely to exhibit aggressive behaviours. It can serve as a buffer against noncompliance with society.On the other hand, life dissatisfaction is associated with negative health outcomes, negative psychological conditions and suicidal behaviours. (Kwan, 2008). In the light of the data on the concepts of life satisfaction and leisure satisfaction in the literature,it can be said that high levels of satisfaction with life and leisure make positive contributions to the quality of life of individuals. When the studies on this subject are examined, life satisfaction (Ayhan, Eskiler, Soyer, 2017; Bastug, 2009; Cecen, 2007; Cetinkaya, 2004; Civitci, 2009; Goc, 2008; Huebner, 2004; Kong and You, 2013; Kumartasl1, 2010; Kwan, 2008; Proctor, Linley and Maltby, 2010; Selcukoglu, 2001; Suldo and Huebner, 2006; Toros, 2002; Yerlisu Lapa, AgyarveBahadir, 2012; Yetim, 1991) and leisure satisfaction concepts (Agyar, 2014; Ardahan and Lapa, 2010; Chen, Li and Chen, 2013;Cakir, 2017; Celik, 2011; Karli, Polat, Uzum and Kocak, 2008) are discussed separately.

This study was prepared by considering that the need for leisure is a necessity for each individual and that the concept of recreation has a universal qualification. The increase of the leisure satisfaction level with participating or after participating to the activity may be thought to be closely related to the level of life satisfaction. In this context, it is aimed to investigate the relationship between life and leisure satisfaction of individuals who participate in leisure activities within outdoor recreation in a different culture and geography.Therefore, it is thought that the results obtained from the research will contribute to therelevant literature in terms of determining the relationship between life and leisure satisfaction of the individuals who are interested in outdoor recreation and revealing the relationship between them.

\section{Method}

Sample: The population of the study is comprised of individuals attending recreational activities in London, England.In the sample group, there are active participants in recreation areas such as parks and gardens. A total of 500 individuals, (females $n=298$ and males $n=202$ ), aged between 12 and 65 years participated in the study.Simple random sampling method was used when participants were determined. These participants are volunteers who participate in outdoorleisure activities.

Data Collection Tools: Two different measurement tools were used in this study.In order to determine the life satisfaction of the participants, "Life Satisfaction Scale"developed by Diener (1985), andadapted to Turkish by Köker (1991) and Yetim (1991), was used.In consist of 5 items prepared in 7 point Likert scale. Preference options for the items in the scale are listed as "Strongly Disagree (1)", "Disagree (2)", "Partially Disagree (3) "Neutral (4)", "Partially Agree (5)", "Agree (6)", and "Strongly Agree (7)". Another scale developed by Beard and Ragheb (1980), which was studied to adapt into Turkish by Gökce and Orhan (2011), is "the Leisure Satisfaction Scale" consisting of 24 items 
and 6 sub-dimensions (Psychological, Educational, Social, Relaxation, Physical and Aesthetics) and the mean score. Scale items are scored in the form of "Almost (3)", "Often True (4)", "Almost Always True (5)". In this scale, it is aimed to determine the perception level of needs that individuals gain in their free time. For this study, Cronbach's Alpha coefficients were examined to determine the internal consistency of the scales. The coefficients were found .80 for life satisfaction scale and .86 for leisure satisfaction scale.

Data Collection: After obtaining the necessary permissions for the scale forms, questionnaires were applied by the researcher with the method of one-on-one interview.Accordingly, they were asked to visit famous open areas in the city centre such as Hyde Park, Green Park, St. James' Park, and Regent's Park and to evaluate the scale forms. Before the participants were given the measurement forms, they were informed about the content of the research. Also, they approved that they are into recreation actively and participated in the study voluntarily. With the evaluation of the obtained data, ones which are inappropriate for the study, are detected as Never True (1)", "Seldom True (2)", "Sometimes True

incomplete information, are loss of information are excluded from the study. Thus, fully completed 500 participant forms were evaluated.

Data Analysis: The fully completed data obtained from the measurement tool form were transferred to the statistical package program in the electronic environment for statistical analyses. Percentage, frequency, mean score and standard deviation values of the data were determined by producing its descriptive statistics. Pearson correlation coefficient and simple linear regression analysis were used to interpret the level of the relationship between the scores of the scales. Significance level was taken into consideration as $\mathrm{p}<.01$ in the statistical analyses and interpretation of the data.

\section{Findings}

Descriptive statistics of participants about life and leisure satisfaction levels are given in Table 1 .

Table 1. Descriptive Statistics of Participants on the Levels of Life and Leisure Satisfaction

\begin{tabular}{lccc}
\hline & $\boldsymbol{n}$ & total & $\boldsymbol{s d}$ \\
LifeSatisfaction & 500 & 26.15 & 4.83 \\
\hline Psychological & $\boldsymbol{n}$ & mean & sd \\
Educational & 500 & 3.96 & .64 \\
Social & 500 & 3.73 & .73 \\
Physical & 500 & 3.78 & .71 \\
Relaxation & 500 & 4.10 & .65 \\
Aesthetics & 500 & 3.85 & .72 \\
Leisure Satisfaction & 500 & 3.65 & .65 \\
\hline
\end{tabular}

When Table 1 is examined, it can be seen that the life satisfaction of the participants has an average of 26.15 out of 35 . When the leisure satisfaction is

the lowest one belongs to "Aesthetic" subdimension with 3.65.The total average of the leisure satisfaction scale is 3.84 examined; it is seen that the highest average belongs to "Physical" sub-dimension with4.10 and

Table2. RelationshipCoefficients of Participants' Life SatisfactionandLeisureSatisfaction

\begin{tabular}{|c|c|c|c|c|c|c|c|c|}
\hline & 1 & 2 & 3 & 4 & 5 & 6 & 7 & 8 \\
\hline 1. Life Satisfaction & - & & & & & & & \\
\hline 2. Psychological & $.313^{* *}$ & - & & & & & & \\
\hline 3. Educational & $.157^{* *}$ & $.462^{* *}$ & - & & & & & \\
\hline 4. Social & $.262^{* *}$ & $.354^{* *}$ & $.424^{* *}$ & - & & & & \\
\hline 5. Physical & $.230^{* *}$ & $.409^{* *}$ & $.252^{* *}$ & $.295^{* *}$ & - & & & \\
\hline 6. Relaxation & $.229^{* *}$ & $.437^{* *}$ & $.190^{* *}$ & $.196^{* *}$ & $.369^{* *}$ & - & & \\
\hline 7. Aesthetics & $.246^{* *}$ & $.299^{* *}$ & $.296^{* *}$ & $.256^{* *}$ & $.232^{* *}$ & $.296^{* *}$ & - & \\
\hline 8. Leisure Satisfaction Total & $.362^{* *}$ & $.744^{* *}$ & $.676^{* *}$ & $.647^{* *}$ & $.639^{* *}$ & $.636^{* *}$ & $.597^{* *}$ & - \\
\hline
\end{tabular}
* $p<.01$

In accordance with the findings obtained, while there was a medium statistical correlation between the total scores of life satisfaction and leisure satisfaction of the participants $(r=.36 ; p<.01)$, There was a moderate relationship between life satisfaction and leisure satisfaction sub-dimensions (psychological $\mathrm{r}=.31$; educational $\mathrm{r}=.16$; social $\mathrm{r}$ $=.26$; physical $\mathrm{r}=.23$; relaxation $\mathrm{r}=.23$ and aesthetic $\mathrm{r}=.25)($ Table 2$)$. 
Table3. Simple linear regression analysis to predict life satisfaction status with the level of leisure satisfaction of participants

\begin{tabular}{cccccccc}
\hline Variable & & & & & & \\
B & StandardError & $\mathrm{R}$ & $\mathrm{R}^{2}$ & $\beta$ & $\mathrm{T}$ \\
\hline LeisureSatisfaction & 3.902 & .450 & .362 & .131 & .362 & $8.669 *$ & $75.158^{*}$ \\
\hline
\end{tabular}

Table 3 shows the regression equation; Y $($ dependent variable-life satisfaction $)=a($ constant coefficient $)+b$ (coefficient of the independent variable) * X (independent variable-leisure satisfaction) and when the results are examined, it is seen that total leisure satisfaction level explains life satisfaction significantly $\left(R=.362, R^{2}=.131\right.$, $F=75.158, \quad p<.001)$. According to these results, total leisure satisfaction level explains $13.1 \%$ of the variance in life satisfaction value.

\section{Discussion-Conclusion}

As a result of the study, it is seen that life satisfaction of individuals who participate in outdoor recreation activities in parks and gardens has increased positively and that there are leisure satisfactions and according ly psychological and physiological acquisitions. For this reason, while life satisfaction levels of individuals with high leisure satisfaction, who participate in outdoor activities such as parks and gardens, are expected to be high, it is recommended that local governments should give more space to outdoor park and garden recreation activities.

Life satisfaction of the participants was found to have an average of 26.15 out of 35 . It is presented that the highest average belongs to "Physical" sub-dimension with4.10 and the lowest one belongs to "Aesthetic" subdimension with 3.65.The total average of the leisure satisfaction scale is 3.84. Yerlisu Lapa (2013) found in her study on individuals participating in the recreation park in Turkey in 2013 that the leisure satisfaction level in the highest relaxation sub-dimension (4.62) and lowest in the psychological sub-dimension (3.55). These results express that leisure satisfaction differs in societies with regard to their satisfaction levels and the domains.. When the studies on the relationship between leisure satisfaction and life satisfaction were examined, Brown and Frankel (1993), Huang and Carleton (2003), Kovacs (2007), Yerlisu Lapa (2013), Chick et al. (2016) found a positive relationship between life satisfaction and leisure satisfaction. In the study on retired individuals by Guinn (1999), it was found that the behaviour towards leisure motivation was originated from intrinsic motivation and it was concluded that this situation was positively related to life satisfaction. When the literature on leisure satisfaction is examined, it is seen that in Turkey and the world, there is limited number of studies on the relationship between life satisfaction and leisure satisfaction. The results of this study are in parallel with the existing studies in the literature. In a study examining the relationship between recreational satisfaction and life satisfaction, it was found that the correlation coefficients between life satisfaction and leisure satisfaction of the individuals attending summer sports schools were significantly differentiated (Küçük Kılıç et al., 2016).

In addition, the result of simple linear regression analysis reveals the total value of leisure satisfaction and life satisfaction significantly. It can be seen that the increase in leisure satisfaction affects the life satisfaction of individuals consuming their free time in parks and gardens in a positive way and this situation is explained with $13.1 \%$ variance value. In a study conducted by Liang et al. in 2013 on individuals living in China, Japan and South Korea, values of leisure satisfaction and quality of life were examined. When the obtained findings were analysed in terms of logistic regression, it is concluded that leisure satisfaction levels of Asian people in the study have a positive effect on quality of life. This result coincides with the findings of research with similar characteristics. With such studies to be carried out in our country, it is very important to identify outdoor recreation demands for parks and gardens, to make plans for activities and make them available to the public. The enjoyment and satisfaction of the individuals who spend their free time in parks and open spaces can affect the quality of life and provide the opportunity to get pleasure out of life. In order to implement recreation policies in our country in a more effective and efficient way, overseas examples of similar studies can be examined. The fact that the research group consists of participants who spend their free time in gardens and parks only in London, England can be considered as a limitation of the research. For this reason, in some regions in Turkey where there are large parks and gardens, it is thought that the study on samples with larger and different characters will contribute to the literature by evaluating it in terms of different independent variables.

\section{References}

1. Ağyar, E. (2014). Contribution of perceived freedom and leisure satisfaction to life satisfaction in a sample of Turkish women. Social Indicators Research, 116(1), 1-15.

2. Ardahan, F. ve Yerlisu Lapa, T. (2010). An Examination of Leisure Satisfaction Level of University Students with regard to Genderand Income. Hacettepe J. of SportSciences, 21(4), 129-136.

3. Ardahan, F., Kaplan, A. (2017). OutdoorRecreation. (Ed. Faik Ardahan). Detay Publishing. p.1-2, Ankara.

4. Ardahan, F. ve Lapa Yerlisu, T. (2011). Outdoor recreation: there a son sand carried benefits for attending outdoor sports of the participants of cyclingand/or trekking activities. International Journal of Human Sciences. 8(1): 1328-1341.

5. Ayhan, C., Eskiler, E., Soyer, F. (2017). The Effect On the Life Satisfaction and Quality of Life of the Factors That Can Prevent Participation of Active Athletes in Recreational Activities. ERPA International Congresses on Education. Book of Proceedings, pp.164-175. 
6. Baștuğ, G. (2009). The Investigation Of Relation Between Empathic Skill And Life Satisfaction Of Volleyball Trainer Candidates. Nigde University Journal of Physical Education and Sport Sciences, 3(3), 222-227.

7. Beard, J.G. ve Ragheb, M.G. (1980). Measuring Leisure Satisfaction. Journal of Leisure Research. 12(1): 20-33.

8. Beşikçi, T. (2016). Investigating The Relatıonshıps Between Sensation Seeking, Leisure Motivation And Leisure Satisfaction In Adventure Recreation: Sample Of Ultralight Aircrafts Pilots (Master Thesis), Manisa Celal Bayar University, Institute Of Social Sciences. Manisa

9. Brown BA, Frankel BG. (1993). Activity throught the years leisure: Leisure satisfaction and life satisfaction. Sociology of SportJournal, 10, 1-17.

10. Chen, Y. C., Li, R. H. andChen, S. H. (2013). Relationships among adolescents' leisure motivation, leisure involvement, and leisure satisfaction: A structural equation model. Social Indicators Research, 110(3), 1187-1199.

11. Chick G, Hsu YC, Yeh CJ \&Hsieh CM (2015) Leisure Constraints, Leisure Satisfaction, Life Satisfaction, and SelfRatedHealth in SixCities in Taiwan, LeisureSciences, 37:3, 232-251.

12. Chick G, Hsu YC, Yeh CK, Hsieh CM, Bae SY \&Iarmolenko S. (2016). Cultural Consonance in Leisure, Leisure Satisfaction, Life Satisfaction, and Self-Rated Health in Urban Taiwan, Leisure Sciences, 38:5, 402-423.

13. Cakır, V. O. (2017). The Relationship Between University Students' Leisure Satisfaction Levels and Leisure Management. Gaziantep University Journal of Sport Science. 2(3): 17-27.

14. Çalık, F., Başer, A., Ekinci, N.E. ve Kara, T. (2013). Sportive Recreation Potential Modeling of Nature Parks (Ballıkayalar Nature Park Example). Journal of Sport Management and Information Technology. 8(2): 35-51.

15. Çeçen, A. R. (2007). An Investigation of University Students' Social and Emotional Loneliness Levels According to Their Genderand Life Satisfaction. Mersin University The Journal of Education Faculty, 3(2), 180-190.

16. Çelik, G. (2011). Analyse Leisure Constraints and Satisfaction of Disabled People Working In Public Sector (Antalya City Center). (Master Thesis). Akdeniz University, Antalya.

17. Çetinkaya, H. (2004). The Levels of Body Image, Pleasure Of The Body Organs, Self-Esteem, Life Satisfaction and Social Compertion Differentials According to Demographic Variables. (Master Thesis). Mersin Üniversity, Mersin.

18. Çivitci, A. (2009). Life Satisfaction in Junior High School Students: The Role of Some Personal and Familial Characteristics, Uludag University The Journal of Education Faculty. 22(1), 29-52.

19. Diener, E., Emmons, R. A., Larsen, R. J., \&Griffin, S. (1985). The satisfaction with Life Scale. Journal of Personality Assessment, 49 (1), 71-75.

20. Göç, Z. (2008). Predictive role of perfectionism on academic achievement and life satisfaction. Unpublished master dissertation. Boğaziçi University, İstanbul.

21. Gökçe, H. \& Orhan, K. (2011). Validity and Reliability Study of the Leisure Satisfaction Scale (LSS) into Turkish, Hacettepe J. of Sport Sciences. 22 (4), 139-145.

22. Guinn, B. (1999). Leisure Behavior Motivation and the Life Satisfaction of Retired Persons. Activities, Adaptation \&Aging. 23(4): 13-20.

23. Hong, S.M., Giannakopoulos, E., (1994). The Relationship of Satisfaction with Life to Personality Characteristics, Journal of Psychology Interdisciplinary\&Applied, 128(5), p.p. 547-558.

24. Huang CY, Carleton B.(2003). The relationships of leisure participion, leisure satisfaction and life satisfaction of college students in Taiwan. Journal of Exercise Scienceand Fitness, 1(2), 29-132.
25. Huebner, E. S. (2004). Research on assessment of life satisfaction of children and adolescents. Social Indicators Research, 66, 3-33.

26. Karl, Ü., Polat, E., Üzüm, H. ve Koçak, S. (2008). The Leisure Satisfaction Levels Of University Students. 10. International Sports Sciences Congress, Bolu, Turkey.

27. Koçyiğit M., Yıldız M. (2014). Recreation Applications in Local Administrations: The Sampleof Konya City, International Journal of Science Cultureand Sport, 2: 211-223. 28. Kovacs, A. (2007). The Leisure Personality: Relationships Between Personality, Leisure Satisfaction, and Life Satisfaction. (Unpublished master dissertation) USA: Indiana University, School of Health, Physical Educationand Recreation.

29. Kong, F. andYou, X. (2013). Loneliness and self-esteem as mediators between social support and life satisfaction in late adolescence. Social Indicators Research, 110, 271-279.

30. Köker S. (1991). Comparison of Life Satisfaction Levels of Normal and Troubled Adolescents. (Unpublished master dissertation). Ankara University, Institute Of Social Sciences. Anakara

31. Kumartaşl1, M. (2010). Investigate The Attitudes Of Second Level Students In Physical Education Course And Their Life Satisfaction Level.(Unpublished master dissertation). Gazi University, Ankara.

32. Küçük Kılıç, S., Lakot Atasoy, K., Gürbüz, B., Öncü, E. (2016).An Examination of Relationship Between Leisure Satisfaction and Life Satisfaction. IUÜ Journal of Sport Sciences, 6(3), 56-70.

33. Kwan, Y. K. (2008). Life satisfaction and family structur eamong adolescents in Hong Kong. Social Indicators Research, $86,59-67$.

34. Liang, J., Yamashita, T., Brown J.S, (2013). Leisure satisfaction and quality of life in China, Japanand South Korea : a comparative study using Asia Barometer 2006. Journal of Happiness Studies. 14 (3), 753-769.

35. Losier, G.F., Bourque P.E. ve Vallerand R.J. (1993). A Motivational Model of Leisure Participation in The Elderly. The Journal of Psychology. 127(2): 153-170.

36. Ocak, E. (2006). An Evaluation About Istanbul's Historical Parks From The Viewpoint Of Nowadays Usage Functions. (Master Thesis). İstanbul Teknik University, İstanbul.

37. Proctor, C., Linley, P. A. And Maltby, J. (2010). Very happy youths: Benefits of veryhigh life satisfaction among adolescents. Social Indicators Research, 98, 519-532.

38. Selçukoğlu, Z. (2001). Evaluation of the relationship between the level of burnout and loneliness level and life satisfaction in research assistants in terms of some variables. (Unpublished master dissertation). Selçuk University, Konya. 39. Sunal, B. (2015). London's FamousParks. http://www.makaleler.com/londra-parklar\%C4\%B1.

(03.10.2016).

40. Suldo, S. M. And Huebner, E. S. (2006). Is extremely high life satisfaction during adolescence advantageous? Social İndicators Research, 78, 179-203.

41. Toros, T. (2002). Goal Orientation, Motivational Climateand Life Satisfaction Among Elite and Non-Elite Male basketball players in Turkey. Hacettepe Journalof Sport Sciences, 13(3), 24-36.

42. Tütüncü, Ö. (2014). Society and Outdoor Recreation Activities: USA Case. Anatolia: Journal of Tourism Research, 25, (1): $118-120$.

43. Yetim Ü. (1991). Life Satisfaction in terms of Organization and Pattern of Personal Projects, (Unpublished PHD dissertation): Ege University, İzmir

44. Yerlisu Lapa, T. (2013). Life Satisfaction, Leisure Satisfaction and Perceived Freedom of Park Recreation Participants. Procedia - Social and Behavioral Sciences, Volume 93, 1985-1993.

45. Education And Sport Teachers (Kayseri City Example) SPORMETRE Journal of Physical Education and Sports Sciences, 2012, 10(2), 53-59. 